\title{
Kønnets regerende dronning \\ - en introduktion til køn og krop
i Judith Butlers forfatterskab
}

Af Christel Stormhøj

Er det muligt at tanke køn som andet end binare modsatningspar? Artiklen introducerer filosoffen Judith Butler og viser, bvordan kon kan tankes ud over faste kategovier som hetero- og bomoseksualitet. amerikansk filosof og professor i retorik, kaldes for "kønnets regerende dronning". Karakteristikken er velvalgt, eftersom Butlers teori om kønnet har haft en afgørende indflydelse på store dele af den aktuelle kønsteori og seksualitetsforskning.

Butlers hovedtese er, at det ikke kun er det sociale og kulturelle køn, der kan defineres ud fra de herskende diskurser. Også det biologiske køn er diskursivt bestemt. ${ }^{2}$ Køn ses som en proces, hvorunder kroppen og subjektet antager kønsspecifik form gennem en kontinuerlig identifikation, der består af en gentagende citering af de herskende kønsnormer. Køn har status af et eksistensvilkår, eftersom to-kønnetheden, som Butler kalder påtvungen heteroseksualitet, udgør støbeformen for kroppens og subjektets væren og forståelighed. To-kønnetheden menneskeliggør.

Anledningen til at jeg har valgt at introducere Butler, er hendes teoris fornyende og sine steder også originale bidrag til det 
kønsteoretiske felt. Min artikel vil falde i 4 dele. I del 1 vil jeg indkredse de teoretiske perspektiver, som ligger til grund for Butlers tankeunivers og placere hendes tekster i relation til forskningsfelter. Butlers kritik af køns- og seksualitetskategorier, der hviler på en problematisering af identitetsbegrebet som normativt udgangspunkt, fremstilles i del 2. I forlængelse heraf redegør jeg for hendes kritik af skellet mellem sex og gender, som dele af kønsforskningen bygger på. Skellet er problematisk, eftersom det hviler på heteroseksualitet som norm. Butlers performative teori om kønnet fremstilles i del 3. Teoriens udgangspunkt er både magtanalytisk og psykoanalytisk: Den sammenkæder elementer fra en foucauldiansk forståelse af subjektet som produkt af magten med elementer fra en lacaniansk teori, hvor subjektet ses som splittet for sig selv. Butlers absolutte genistreg består i, at hun reformulerer dannelsen af det kønnede subjekt indenfor en talehandlingsteoretisk (performativ) ramme. I del 3 berøres endvidere spørgsmålet om individets handlemulighed vis à vis diskurserne. Del 4 udgøres af en kritisk vurdering af Butlers bidrag til det aktuelle kønsteoretiske felt. ${ }^{3}$

\section{DET TEORETISKE UNIVERS}

Det er, som antydet, en række ræsonnementer fra den poststrukturalistiske strømning indenfor filosofi, psykoanalyse og sprogvidenskab, som Butler bygger sin teori på. ${ }^{4}$ Denne bølge forbindes især med teoretikere som Foucault, Lacan og Derrida, og Butler inddrager dem da også hver især.

Hun forstår kønnet som en konstruktion, der har indlejret sig i individet gennem historisk og kulturelt specifikke diskurser. Her følger hun Foucaults teori om subjektet som en social konstruktion og foretager en kønsteoretisk reformulering af den. ${ }^{5}$ Den magtanalytiske tilgang bruges til at understrege den voldelige normativitet, der styrer konstruktionen af kønnet. Butler går også delvist i Lacans spor, idet hun betrag- ter det kønnede subjekt som skabt gennem identifikationsprocesser. Kønsidentitet etableres gennem identifikation med positioner i en kønnet symbolsk orden indenfor lacaniansk psykoanalyse. Da positionerne er symbolske, eftersom de har karakter af idealer, vil identifikationerne altid kun være tilnærmelsesvise. Butlers hensigt med at inddrage en psykoanalytisk forståelse er netop at betone køns-identitetens grundlæggende instabilitet. Imidlertid gør Butler også op med Lacan i en sådan grad, at det synes som om, hun mimer ham ihjel. Især den heterosexisme, som hans forståelse af kønsforskel implicit hviler på, likvideres.

Endelig inddrager Butler Derridas opfattelse af betydning som relationel. Enhver identitet far betydning i relation til det, den sættes i opposition til eller det, den afgrænser sig fra. Identitet er således et resultat af eksklusion; af etablering af et i Derridask forstand "konstitutivt udenfor". Identitetens konstitutive udenfor er både dens muligheds- og umulighedsbetingelse. $\mathrm{Mu}^{-}$ lighedsbetingelse fordi identitet ikke ville være det, den er uden eksklusion; altså afgrænsning fra det andet. Og umulighedsbetingelse eftersom det konstitutive udenfor er det, som hindrer identiteten $i$ at etablere sig endeligt; det fraspaltede andet er hele tiden tilstede i identiteten. Butler anvender ræsonnementet i opgøret med Lacan og den fiksering af identitet, som er iboende de symbolske positioner. Det konstitutive udenfor bruges som en metafor for en kritisk ressource, der kan anvendes til at udvide den indskrænkning af kønnet, som ligger $\mathrm{i}$ at tænke det heteroseksuelt.

\section{FORSKNINGSFELTER OG INTERN KRITIK}

Butlers tekster handler om køn og seksualitet, og de hører derfor til et sted mellem køns- og seksualitetsforskning. Mere præcist kan de siges at kile sig ind i mellemrummene mellem forskellige perspektiver; feministisk teori henholdsvis queer theory (Butler 1997a: 1, 1992: 85). ${ }^{6}$ Når Butler 
arbejder i mellemrummene, er det for at udfordre rodfæstede forestillinger og indbyrdes afgrænsninger (Butler 1997a: 2). Gender Trouble (1990a) rettede en sønder-
Det problematisk polariserede forhold mellem forskellige feministiske diskurser på den ene side og queer theory på den anden har også Butlers kritiske bevågenhed (But-

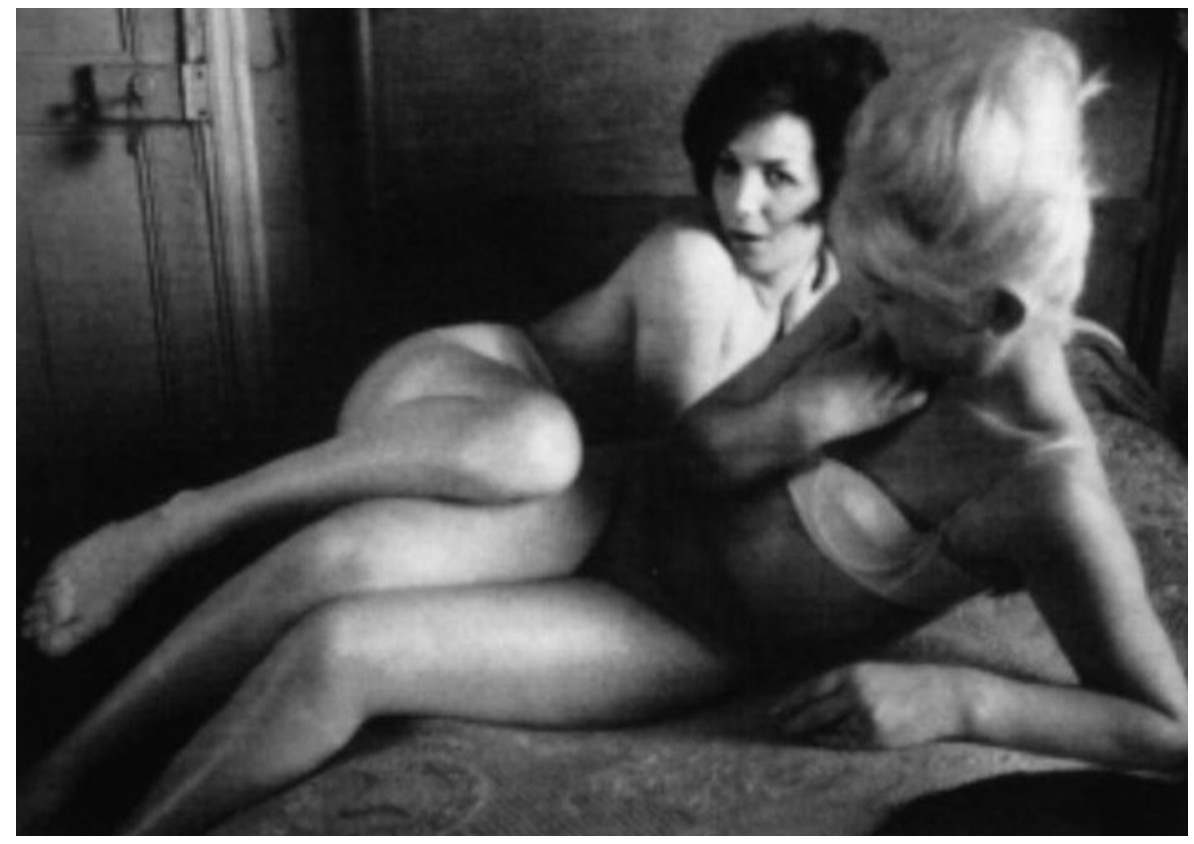

Copyright: Christer Strömholm/Nina Beskow. Gengivet med Nina Beskows venlige tilladelse.

lemmende kritik imod den implicitte heteronormativitet, den rigide kønsdikotomitænkning, som er på spil i megen feministisk teori. Det blev opfattet som en queer afsked med feminismen, selvom kritikken var ment som et forsøg på at bane vejen for en alliance mellem perspektiverne (Butler 1997a: 2). Forudsætningen for et frugtbart samarbejde var, at de feministiske diskurser opgav deres meddelagtighed i en heterocentrisk forestilling om kønnene. ler 1992; 1997a). Hun opponerer imod den arbejdsdeling, der har etableret sig, hvor køn ses som den feministiske teoris anliggende, medens seksualitet betragtes som queer teoriens og gay and lesbians studies priviligerede genstand.7 Konsekvensen af opdelingen er reduktionistisk i mindst to henseender. For det første ignoreres den feministiske traditions bidrag til studiet af seksualitet som et socialt og historisk fænomen. Og for det andet ses der bort fra, at 
køn er en central dimension i reguleringen af seksualitet, hvad enten denne er af homo- eller heteroseksuel karakter. ${ }^{8}$ Skellet er altså ikke kun falskt, men også farligt, eftersom det indebærer en indsnævring af såvel forståelsen af køn som af seksualitet. Faren for reduktionisme undgås kun, hvis man fastholder nødvendigheden af at arbejde med kønnets og seksualitetens indbyrdes relationer. Det er Butlers ærinde.

\section{Magtens IDENTITETSKATEGORIER/ IDENTITETSKATEGORIERNES MAGT}

Butlers projekt er et opgør med forestillingerne om naturlige, adskilte og faste identitetskategorier. Hendes kundskabsteoretiske udgangspunkt er, at identitet forudsætter identifikation, der altid kun vil være tilnærmelsesvis, og at identitet derfor bygger på eksklusion af forskel. Det medfører, at ingen identitet kan betragtes som selv-identisk. Endvidere implicerer det, at der ikke kan etableres faste grænser mellem identiteter i og med, at identiteter ikke er homogene (Butler 1993b: 316). Identiteterne kvinde, lesbisk etc. kan således ikke ses som internt kohærente, da der er forskelle imellem kvinder, imellem lesbiske etc. Grænserne mellem feminitet og maskulinitet kan heller ikke tænkes som faste, eftersom en feminin identitet for eksempel bygger på eksklusion af maskulin identifikation. Konsekvenserne er at såvel kønsidentitetskategorierne, som dele af kønsforskningen hviler på, som forestillingen om stabile seksuelle identiteter, som megen hidtidig seksualitetsforskning har bygget på, udfordres. Indenfor begge forskningsfelter har man antaget, at kvinder henholdsvis homoseksuelle udgjorde homogene grupper, som kunne afgrænses og defineres som analyseobjekter. Endvidere har man forudsat, at identiteterne kvinde og homoseksuel var fuldstændige.

Årsagen til, at det er nødvendigt at gøre op med identitetskategorier som forskningens udgangspunkt, er, at kategorierne er effekter af diskurser, der altid implicerer magtforhold. Det betyder, at de altid indgår i hierarkiserings- og marginaliseringsprocesser. For hvordan skal man for eksempel afgøre, hvad der definerer en "rigtig" lesbisk, og hvem eller hvilke instanser skal fastsætte det? Diskurserne strukturerer indholdet i kategorierne. De fastsætter, hvordan kategorierne kommer til at se ud, og hvordan de skal fortolkes. Kategorierne virker altså regulerende, idet de medfører bestemte normativt fastlagte definitioner af for eksempel lesbisk identitet. 9 Det er på den baggrund, at Butler hævder, at identitetskategorierne altid indebærer politiske disciplinerings- og normaliseringsprocesser. De vil altid medføre afvisning af identitetens "andethed", og de vil altid resultere $\mathrm{i}$ eksklu- sion af nogle af dem, som forskningen har til hensigt at repræsentere (Butler 1990a: lff \& 142, 1990b: 324, 1993b: 308).

\section{SEX-GENDER TRADITIONEN OG HETEROSEKSUEL MATRIX}

Med baggrund i kritikken af identitetsbegrebet står den "klassiske" feministiske teori, der bygger på en enhedslig kategori, kvinde, i fare for knock'out. ${ }^{10}$ Problemet med kategorien kvinde er dels, at den forudsætter lighed imellem dem, som inkluderes $\mathrm{i}$ den. Og dels at feministisk teori selv skaber diskurser om kvinder, og derfor selv deltager i magtens disciplinering og normalisering via definitionen af en kvindelig identitet (Butler 1990a: 5).

For at løse problemet dekonstruerer Butler den "klassiske" feministiske teoris enhedssubjekt, hvormed hun samtidig gør op med sex-gender traditionen. Den analytiske kategori, gender, blev brugt til at betegne det socialt/kulturelt konstituerede køn i modsætning til sex, der henviste til det biologiske køn. Åbningen mod en radikal adskillelse mellem anatomi og en bestemt identitet var dermed skabt, eftersom distinktionen indstiftede en splittelse mellem sex og gender. Koblingen mellem ana- 
tomi og karakter er på ingen måde legitimeret i teorier om det socialt/kulturelt konstruerede køn. Rent logisk er det muligt at forestille sig, at de kvaliteter, der er blevet forbundet med mandlighed, kunne sammenkxdes med kvindelig anatomi og omvendt.

Den "klassiske" feministiske teori har imidlertid ikke draget de fulde konsekvenser af adskillelses muligheden, eftersom forestillingen om en forbindelseslinie mellem sex og gender fastholdes (Butler 1990a: 6f). Forestillingen bygger på den implicitte antagelse, at socialt køn afspejler det biologiske. Endvidere forstås det biologiske køn som noget prædiskursivt, dvs. som noget naturgivet: Der findes to biologiske køn, som de sociale køn er tolkninger af. Men, kunne man spørge: Hvis den forståelse, vi har af køn, ikke har nogen sammenhæng med et biologisk grundlag, hvordan er det så muligt at erkende et biologisk baseret køn? Forestillingen om kroppen som noget substantielt uafhængigt, der går forud for gender, kan derfor bestrides (Butler 1990a: 7, 1993: 9ff). Forestillingen bygger på en adskillelse mellem natur og kultur, det materielle og det diskursive. Det er en adskillelse, som kan problematiseres blandt andet sprogfilosofisk. Distinktionen synes at være umulig, eftersom vi ikke har nogen prædiskursiv adgang til kropsmaterialiteten. Det materielle får kun betydning indenfor diskurserne, hvilket er det samme som at sige, at al mening gives i sproget. Distinktionen mellem sex og gender viser sig blandt andet på denne baggrund som uholdbar.

I modsætning til den "klassiske" feministiske position kan man argumentere, at skellet mellem sex og gender er en forestilling, som er et resultat af, at en bestemt kønsopfattelse naturaliseres. Det biologiske køn er med andre ord slet ikke før-kulturelt, men i stedet en forestilling der skabes af bestemte diskurser, hvorigennem kønnet naturaliseres, dvs. konstrueres som essentielt (Butler 1990a: 7). Butler går længere med det rxsonnement, eftersom feminis- mens enhedslige og faste subjekt, kvinde, betragtes som skabt indenfor en heteroseksuel matrix (Butler 1990a: 17, 1990b: 335). Den betegner det filter, gennem hvilket kroppe, køn og begær bliver forståelige. Matrixen gør køn begribelig som to kategorier, kvinde og mand, og etablerer en tvingende forbindelseslinie imellem biologisk køn, socialt køn og begærsretning. Samtidig ekskluderer den de subjekter, der ikke fremviser en sådan sammenhæng som uforståelige. Grundlaget for oppositionen mellem kønskategorierne samt kategoriernes interne stabilitet er derfor at finde i en implicit heterosexisme, som den "klassiske" feminisme risikerer at reproducere via fastholdelsen af skellet mellem sex og gender.

Butlers ærinde er ikke kun at bidrage til kritikken af de diskurser, der producerer køn som noget essentielt, men også at udforme sin egen position. Det gør hun via sin performative teori om kønnet.

\section{MATERIALISERING, SUBJEKTIVERING OG PERFORMATIVITET}

Butler søger med sin teori at løse en række problemer, som er internt konstruktivistiske. Problemerne i konstruktivismen er: 1) Spørgsmålet om forholdet mellem materialitet og diskursivitet; 2) Overtagelsesproblemet, hvilket vil sige sprrgsmålet om, hvordan diskurser tilegnes og transformeres til identiteter. Og endelig 3) problemet med et aktivt subjekt, der enten figurerer $\mathrm{i}$ skikkelse af magten, der skaber diskurserne og sætter dem igennem, eller $i$ form af et subjekt, der konstruerer en identitet af dem. Det er ved at reformulere disse problemer indenfor en talehandlingsteoretisk ramme, at Butler etablerer sin egen position. Til grund for den ligger tre hovedkilder: Foucaults redegørelse for hvordan kroppen konstitueres af magten; en lacaniansk forståelse af det imaginære kropsbillede samt en performativ redegørelse for den sproglige betegnelse af kropslige grænser. 
Konstruktionen af køn ses som en proces, der kan benævnes "sexing". Den implicerer en "materialisering", der samtidig er en "subjektivering”, eftersom køn betragtes som skabt indenfor de herskende diskurser. Processen, hvorunder "sex" installeres i individet, betragtes som en dynamisk materialisering. Det, som materialiseres, er bestemte typer af kroppe, og processen finder sted igennem den diskursive praksis.

Diskurs består af performativer, der skaber det, som de benævner gennem normative forskrifter og påbud. Navne, imperativer, anråbelser, trusler, forbud, sanktioner etc. er eksempler på sådanne i Butlers tekster (Butler 1993a: 106). ${ }^{11}$ De har overvejende den funktion at sikre den normative heteroseksualitet ved at foreskrive en tokønnet organiseret forskel. Baggrunden for Butlers forståelse af performativitet er Derridas kritiske reformulering af Austins talehandlingsteori. 12 Performativitet forstår Butler ud fra Derrida som en gentagende og citerende praksis, gennem hvilken diskursen producerer de effekter, som den almindeligvis siges at benævne (Butler 1993a: 2, 1995b: 134). Begrebet citering henviser mere præcist til det forhold, at enhver måde at repræsentere kønnet på citererer, dvs. refererer til kønnets kulturelt forståelige form, omrids og karakter; den måde kønnet opfattes på i den kulturelle kontekst. Det er i den forbindelse væsentligt at pointere, at citeringen ikke kan siges fra, eftersom det er den vedvarende gentagelse af performativerne, der muliggør kønnet (Butler 1992: 84). Det performative moment $\mathrm{i}$ citeringen må da forstås som et led $\mathrm{i}$ en kæde, en gentagelsespraksis. Hvordan performativerne afgrænser kroppen, skal jeg vende tilbage til om lidt.

Ved at anskue kroppen som noget, der materialiseres i den diskursive praksis, er det hensigten at overskride oppositionen mellem materialitet og diskursivitet. Det, der i gængs forstand ses som det "rent" materielle, som kroppen og "sex", betragtes som uundgåeligt med-produceret af det diskur- sive. Diskurserne skaber et forståelsesfilter, der bestemmer, hvad der kan begribes og italesættes som krop og "sex". Kroppen er ikke sprogets kreation, men kropsmaterialiteten eksisterer samtidig med magtrelationer og diskursiv praksis (Butler 1993a: 29). Enhver repræsentation af kvinders og mænds kroppe vil være en formning af dem, eftersom repræsentationen allerede er indlejret i et diskursivt felt, indenfor hvilket kriterierne for, hvad der kan siges om og betragtes som krop og “sex”, fastsættes.

Det er for at forstå kropsmaterialiteten som en aktiv proces, at Foucaults begreb om den produktive magt, og i forlængelse heraf hans redegørelse for subjektiveringen, inddrages (Butler 1993a: 33f, 1997c: 84 \& 90f). Subjektivering betegner en bestemt magtform, der gør individer til subjekter (Foucault 1980: 97, 1982: 212). Det er den proces, hvor individet frembringes som et subjekt gennem en underkastelse under magten. Processen finder sted gennem en disciplinering af kroppen, og individet "formuleres" gennem diskursivt bestemte identiteter såsom mand og kvinde. Identiteten figurerer som et normativt ideal i overensstemmelse med hvilket, kroppen skabes. Der er derfor ikke nogen krop, som ontologisk er adskilt fra magten. ${ }^{13}$

Foucaults forestilling om identitet kobles af Butler sammen med en psykoanalytisk forståelse af det psykiske kropsbillede som en imaginær dannelse (Butler 1993a: 59f \& 72f). Hun trækker en parallel mellem identiteten og det psykiske kropsbillede og ser deres funktion i dannelsen af kroppens materialitet som den samme. I såvel Freuds som Lacans psykoanalyse spiller det psykiske kropsbillede en central rolle for skabelsen af det kropslige subjekt. De argumenterer begge, at oplevelsen af kroppen fremkommer samtidig med billedet af den, og at billedet er imaginært. ${ }^{14}$ Det kropslige subjekt skabes gennem en identifikationsproces, hvor jeg'et identificerer sig med sit spejlbillede, der er at forstå som den andens billede af dets krop. Det indoptagne bille- 
de, der projiceres på kroppen, har en formende kraft, eftersom det samler kroppen og dermed gør den hel.

Den kausalitet, som Butler tillægger det paternal law produces versions of bodily integrity; the name which installs gender (...), works as a politically invested and investing performative $(\ldots)$. To be named is (...) to

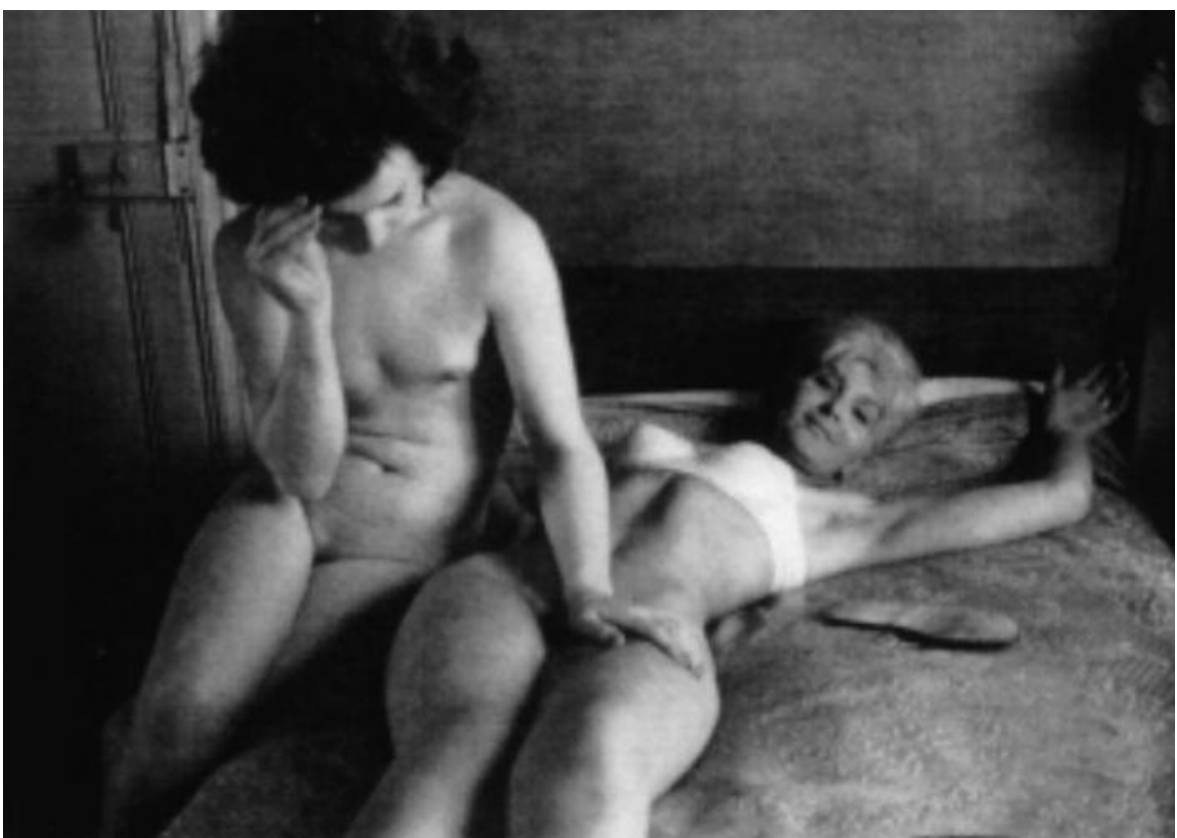

Copyright: Christer Strömholm/Nina Beskow. Gengivet med Nina Beskows venlige tilladelse.

psykiske kropsbillede, er dog begrænset til kroppens konturer, dvs. til det sted, hvor kroppen bliver forståelig. Hun foreslår, at kroppe antager deres materielle form og afgrænsning gennem en performativ anvendelse af sproget. Indenfor en lacaniansk forståelsesramme er sproget, forstået som regler for differentiering, af essentiel betydning for dannelsen og opretholdelsen af kroppens konturer. Kroppens distinkthed opretholdes gennem et kønsmærket navn: "The be formed, bodily, in accordance with the law" (Butler 1993a: 72).

I sin læsning af Lacan gør Butler op med nogle af teoriens forudsætninger. Væsentligst tager hun livet af Lacans forestilling om, at faderloven eksisterer som en tendentiel permanent struktur med basis i en naturgiven heteroseksualitet, der giver den dens autoritet. Lovens autoritative status er udelukkende en effekt af, at den citeres igen og igen, hævder Butler i skarp opposi- 
tion til Lacan. Det skyldes ifølge hende, at faderloven ingen oprindelse har, eftersom heteroseksualitet ikke kan betragtes som det originale, oprindelige og naturlige fundament for kønnet. Det er derfor kun kæden af citeringer, der legitimerer og opretholder loven.

Butler hævder i opgøret med den lacanianske teori, at formningen af kroppen og vedligeholdelsen af dens konturer ikke er en præsocial eller -symbolsk funktion, som Lacan mener. Hun påstår derimod, at det en funktion, der er ledsaget af kriterier for forståelighed, dvs. de binære kønskategorier. Altså hævder hun i modsætning til Lacan, at det heteroseksuelle imperativ i "fader-loven" allerede er tilstede på det niveau, hvor kroppen afgrænses, eftersom kønnet installeres i kroppen gennem et kønsmærket navn. I forlængelse heraf forstår Butler opretholdelsen af kroppens integritet, der oprindeligt tildeltes af spejlbilledet, som et resultat af citering af loven. At citere loven er ensbetydende med at tilegne sig køn gennem identifikationshandlinger indenfor Butlers teoretiske ramme. Gennem lovens forskrifter og forbud reguleres identifikationspraksiser, hvorved nogle kønsidentifikationer bliver mulige, medens andre så godt som umulige. ${ }^{5}$ Individet frembringes som et kulturelt forståeligt subjekt ved, at jeg'et gennemgår den proces, hvorigennem det tilegner sig kønnets materielle mærke; hvor subjektet antager skikkelse af et hun og et han gennem identifikation med foreskrevne symbolske positioner (Butler 1992: 85, 87, 1993a: 96ff).

Den fortsatte opretholdelse af et heteroseksuelt struktureret køn hviler overvejende på to indbyrdes forbundne betingelser. For det første må de, som benævnes han og hun, bekræfte identifikationerne med de foreskrevne positioner igen og igen. De må med andre ord citere dem. For det andet må de frygte det forbudte. Forbuddet installeres gennem truslen om straf, der består i en udelukkelse fra området for kønnets kulturelle forståelighed. Det betegnes som det kulturelt forståelige køns “abjectede yderside". Det er en fra sproget og dermed fra det sociale liv frastødt sfære, der ikke desto mindre befolkes af dem, der ikke kvalificerer sig som legitime subjekter (set fra den hegemoniske diskurs' side vel at mærke) (Butler 1993a: 22, 53). Udelukkelsen fra sproget har også sproget som medium, eftersom det forekommer i skikkelse af forbydende performativer. Ikke mindst de homofobiske anråbelser af den "kvindagtige" bøsse og den "falliske" lesbiske har betydning $\mathrm{i}$ forhold til den påtvungne identifikation med heteroseksualiserede positioner (Butler 1993a: 96 \& 103). Fordømmelserne og den ledsagende trussel om straf skaber en rædsel, der begrænser kommunikationen.

Butlers forståelse af konstruktionen af køn kan sammenfattende og i tilspidset form karakteriseres som et selvkørende maskineri; en kønskonstituerende kæde af citeringer uden et aktivt subjekt.

\section{HANDLEMULighed}

Indenfor Butlers teori kan subjektets handlemulighed ikke garanteres a priori, eftersom subjektet ikke eksisterer før eller uafhængigt af diskurserne (Butler 1995a: 46f, 1995b: 133). Eftersom køn konstitueres som en kxde af citeringer af de herskende kønsnormer, skal muligheden for handlen søges i opholdene mellem citeringerne; i de tilbagevendende øjeblikke, hvor normerne, for at blive opretholdt, er afhængige af at blive citeret igen og igen. Det er med udgangspunkt i forståelsen af kroppe som en dynamisk materialiseringsproces, at der kan øjnes sprækker og mellemrum, som giver plads for subjektivitet. Kløfterne opstår mellem de regulerende normer og de kroppe, gennem hvilke normerne materialiseres via den gentagende citering (Butler 1993a: 220). Kroppe indeholder flere identifikationer og mere begær end dem, som kan trænges sammen i de foreskrevne positioner. Det angiver, at identitet altid er imagi- 
nær. En heteroseksuelt organiseret maskulinitet, for eksempel, skabes gennem det, som bliver udelukket og benægtet, dvs. modsat kønsidentifikation og begær rettet imod eget køn. Det betyder samtidig, at den frastødte "andethed" er inde i maskuliniteten som dens mulighedsbetingelse. Identifikationsprocesserne slår med andre ord fejl, eftersom der ikke kan skabes identitet mellem de herskende heteroseksuelle normer og de identifikationer og begxr, som faktisk eksisterer i mennesker. Sammenlagt indikerer det, at det ekskluderede og afviste, hvilket vil sige den normative heteroseksualitets konstitutive udenfor, kan vende tilbage. Ulydighed og opsætsighed kan forekomme.

Forestillingen om det konstitutive udenfor udgør afsættet for en radikal vision om det politiske, som overskrider konventionelle politiske idealer såsom ressourcemæssig retfærdighed og lige adgang til repræsentation (Butler 1993a: 53). Den overordnede forståelsesramme for undertrykkelse og omstyrtelse/frigørelse er at finde i forestillingen om imaginær identifikation. Med udgangspunkt i sin umiddelbare referenceramme, der angår køn og seksualitet, er det Butlers ambition at generalisere forestillingen om imaginær identifikation til en almen politisk teori, der angår alle identitetsformer og den vedvarende forhandling af dem (Butler 1993a: 115).

\section{EN KRITISK VURDERING}

Der kan ikke herske tvivl om, at Butler med sin performative teori er stærkt medvirkende til at sætte dagsordenen for aktuel kønsteori. Hvorvidt hun tilfører den kønsteoretiske diskurs et nyt og originalt bidrag, synes at være et spørgsmål om bl.a.: 1) Hvilket historisk perspektiv nyhedsværdi og originalitet vurderes ud fra, og 2) om den rekonstruktion og særlige kombination af genealogiske kilder, som hun inddrager ud fra egne problemstillinger, er ny og særegen.

Butlers gentænkning er særegen og der- med kan det siges, at hun er fornyende. Den filosofiske reformulering af kroppen, som hun foretager, er umiddelbart foranlediget af feministiske strategier og queer politik, men de fungerer samtidig også som eksempler, der illustrerer og informerer hendes mere generelle gentænkning af alternative kropsfilosofier. Den væsentligste genistreg består i, at Butler reformulerer en lacaniansk teori om kønnet som en identifikationsproces ud fra Derridas forståelse af performativitet. Dermed kan hun via mange mellemled påvise, at kvinde- og mandekroppe er de materielle effekter af citeringen af de herskende kønsnormer. Den erkendelsesmæssige gevinst er, at opfattelsen af sex som noget "rent" materielt - en naturlig anatomisk forskel, der foreligger før og uafhængig af forståelsen af køn - ikke længere kan opretholdes. Hermed antydes også nogle af anvendelsesmulighederne af teorien. Man kan med den trænge langt ind i en forståelse af vilkårene for og mekanismerne bag kønnets dannelse. Man kan fx pege på den tankemæssige indskrænkethed, der ligger i opfattelselsen af kønnet som heteroseksuelt, der blandt andet resulterer i eksklusion af de subjekter, der ikke lever op til den heteroseksuelle norm.

Når teoriens originalitet vurderes i et historisk perspektiv kan det siges, at Butler står på skuldrene af hele den metafysikkritiske tradition i filosofien, hvoraf Nietzsche, Foucault og Derrida er de seneste. Det gør selvfølgelig ikke hendes teori ringere, men det sætter dens originalitet i relief. Den kan derfor ses som et bidrag, omend et vægtigt, til en allerede igangværende problematisering af metafysiske størrelser. Butler er een blandt flere, som i 1980'erne begyndte at importere det post-strukturalistiske perspektiv til kønsteorien. Samtidig kan hun siges at have ydet et væsentligt bidrag til videreudviklingen af det på en sådan måde, at det alt i alt făr større forklaringskraft og stringens. 16

De umiddelbare forlæg for hendes identifikation af heteroseksualiteten som køns- 
maskineriets støbeform og motor er at finde i Adrienne Richs, Monique Wittigs og delvis også Gayle Rubins udpegning af heteroseksualitet som en politisk institution, der virker disciplinerende. Butler omformulerer imidlertid deres ræsonnementer indenfor en ny referenceramme, dvs. den talehandlingsteoretiske, og forfiner analysen af maskineriets grundelementer og mekanikker betydeligt. Det nye i Butlers fortolkning er, at køn går fra at være et begreb til at blive en aktivitet. Det originale $\mathrm{i}$ hendes analyse består også i pointeringen af, at den kulturelle investering i bestemte ideer om Kvinden, som modsætning til den lange række måder at være kvinde på, bruges til at skabe en indre sammenhæng i det, som Rich betegnede som påtvungen heteroseksualitet, og som skjuler muligheden for mange andre kønnede identiteter. Endvidere kritiseres, hvad jeg finder, at der er god grund til, Richs og Wittigs politiske utopi om lesbianisme som feminismens privilegerede politiske strategi. Kvinders begær imod kvinder er ikke en mindre magt-viden-inficeret størrelse end heteroseksualitet er det. Den er hverken mere eller mindre konstrueret end heteroseksualitet er det, og den eksisterer ikke adskilt fra heteronormativiteten.

Forestillingen om, at der er plads for subjektivitet og potentiel forandring i diskursernes sprækker, har Butler tilfælles med andre, der som hende er lacaniansk inspireret. De franske teorier om kønsforskellen, kendt som "ecriture feminine" og som rummer skikkelser som Helene Cixous, Luce Irigaray og Julia Kristeva, betoner samme idé. Det, som kan bryde igennem i sprækkerne, er strømme af identifikationer og begær, som hører til noget før-sprogligt, og som i en lacaniansk forståelsesramme er noget ubevidst. Formålet med at betone det potentielt omstyrtende i disse strømme er at identificere den platform, hvorfra den binære tankegang, der hviler på en implicit hetero- og fallocentrisme, kan udfordres. Butler følger imidlertid ikke ecriture femi- nine traditionens strategi, der består i en opvurdering af den kvindelige pol i kønsoppositionen for at skabe nye betydninger og udtryk for den. Strategien slår fejl, eftersom fejringen af det feminine ikke indebærer en problematisering af den dikotome kønslogik. I stedet taler Butler om, at der findes en kritisk ressource i det afviste i lacaniansk forstand. Målet med at artikulere de ekskluderede strømme af identifikationer og begær på en anden måde (at reartikulere dem) er for Butler at udvide forståelsen af, hvad der er et kulturelt genkendeligt og socialt legitimt køn.

Butler har helt klart en pointe $\mathrm{i}$ at betone en kritisk resource i det ekskluderede. Så længe det ekskluderede tolkes som en metafor for alt det, vi ikke kan være som kvinder og mænd, fordi vi netop skal være kvinder og mænd, kan det fungere som basis for en kritik af heterocentrismens indskrænkethed. Men jeg har mine forbehold overfor, om det repræsenterer en sandsynlig praktisk-politisk strategi. Eftersom de ekskluderede identifikationer og begær er forbundet med skræk og rædsel i kraft af truslen om straf, er det ikke videre sandsynligt, at de kan mobiliseres som en større kollektiv politisk kraft imod den heteroseksuelle diskurs' overherredømme.

Jeg finder desuden ikke Butlers ambition om at almengøre forestillingen om imaginær identifikation til en altomfattende politisk teori plausibel eller holdbar. Om alle aspekter af undertrykkelse kan reduceres til et spørgsmål om regulering af identifikation er stærkt tvivlsomt. I scenarier, hvor undertrykkelse konstitueres gennem en fysisk indoptagelse af et materielt mærke, såsom sporet af en ulige adgang til mad, slår dette paradigme ikke til. Den franske sociolog Pierre Bourdieu har for længst belært os om, at dominans-undertrykkelsesforholdet mellem de sociale klasser også konstitueres på et fysisk niveau. Det giver sig bl.a. udtryk i differentierede madforbrugsmønstre og følgelig i forskellige kropsformer. Generelt kan det siges, at undertrykkelsesfor- 
hold, der hviler på økonomisk orienterede faktorer, kun vanskeligt kan forstås inden for Butlers teoriramme. Tilsvarende synes forestillingen om, at al omstyrtende praksis spektivet i at teoretisere køn som noget flydende, som en frihed mod enhver fiksering af det, får spændetrøje på, når perspektivet kobles op på det psykoanalytiske begrebs-

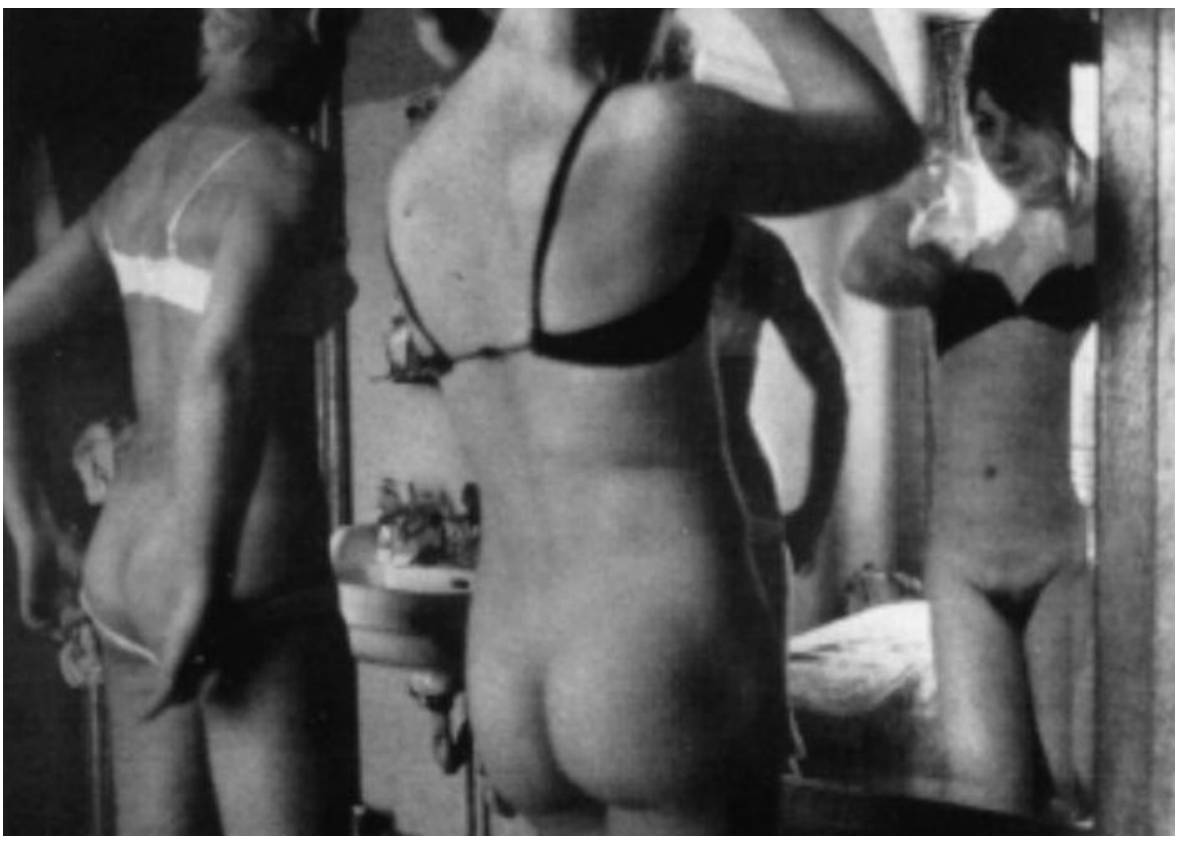

Copyright: Christer Strömholm/Nina Beskow. Gengivet med Nina Beskows venlige tilladelse.

skulle være centreret omkring bestridelsen af normaliserende identitetskategorier reduktionistisk.

En væsentlig begrænsning ved Butlers teori er dens afhængighed af lacaniansk psykoanalyse. Butler er med sit udgangspunkt i Lacans statiske hetero- og fallocentriske fortælling om kønnet negativt bundet til den. Det medfører bl.a., at den spræng- og innovationskraft, der ligger $i$ at anskue køn som noget performativt, reduceres. Per- apparat. Når Butler dekonstruerer den lacanianske fortælling, er hun lige præcis fanget af den; tvunget til at negere den. Hendes utrættelige forsøg på at symptomaflæse Lacan; at lede efter effekterne af hans ubevidste (fortrængningerne, der er hans teksters mulighedsbetingelse) er indicier herpå. Jeg har mine tvivl ved, om kønsteorien radikalt fornyr sit begreb om køn ved at pleje omgang med psykoanalyse og i særdeleshed at bruge energi på at dissekere afdøde, psyko- 
analytiske koryfæers ubevidste for at vriste kønnet fri af den heteroseksuelle norm.

\section{NOTER}

1. Betegnelsen er Gayle Rubins, og den stammer fra interviewet, "Sexual Traffic" (Butler 1997b: 104).

2. Skellet mellem sex og gender, der har haft afgørende indflydelse på forståelsen af køn som en social/kulturel konstruktion, blev første gang formuleret af netop den tidligere omtalte Rubin i artiklen, "The traffic in Women: Notes on the 'Political Economy' of Sex" (Rubin 1975).

3. Dele af artiklen bygger på min ph.d.-afhandling, Kønnet vi tonker, kønnet vi gør, udgivet af Sociologisk Institut, Københavns Universitet (Stormhøj 1999). Tak til Dag Heede, Mette Stømfeldt, Dorte Marie Søndergaard samt redaktøren for værdifulde kommentarer og diskussioner under udarbejdelsen af artiklen. Også tak til de studerende i feministisk teori på Institut for Statskundskab for deres spidsfindige spørgsmål og kommentarer, der har hjulpet mig til en yderligere afklaring og tydeliggørelse af min fortolkning af Butler.

4. Poststrukturalisme er ikke at betragte som en teori i traditionel forstand, men er snarere en række kritiske strategier, der undersøger, hvordan sandhed skabes (sandheden om fx. mennesket, kønnet, seksualiteten, det sociale etc.). Formuleret bredt indebærer poststrukturalismen en kritik af metafysikken, dvs. af begreber om kausalitet, identitet, subjekt og sandhed, og strukturalismens opfattelse af tegnet. Oftest anvendes også psykoanalytiske tankefigurer i strategierne. Jf. Sarup 1988; Simonsen 1996; Young 1981.

5. Det er først og fremmest Foucaults værker fra hans mellemperiode, der udgør afsættet for Butler - primært Overvågning og Straf samt det første bind i Seksualitetens Historie.

6. Det er det poststrukturalistiske perspektiv indenfor studiet af seksualitet, som betegnes queer theory. Perspektivets primære analyseobjekt er oppositionen mellem hetero- og homoseksualitet, der betragtes som en diskursiv kategori, en måde at definere og strukturere identitet, begær, adfærd og sociale relationer på. Queer theory udfordrer heteroseksualiteten ved at anskue den som en diskurs eller en magtstruktur. Jf. også Kulick 1996; Lindholm 1996; Seidman 1995. Ordet queer betyder mærkelig eller afvigende og er blevet brugt som et skældsord om homoseksuelle i den angelsaksiske verden.
7. I den nu klassiske artikel, "Thinking Sex: Notes for a Radical Theory of the Politics of Sexuality" (Rubin 1984), argumenterede Gayle Rubin for et metodologisk skel mellem studiet af køn og seksualitet. Distinktionen etableredes ud fra en forståelse af, at køn og seksualitet udgør basis for distinkte og dermed adskilte sociale handlinger og strukturer. Seksuelle handlinger kan derfor ikke analyseres udfra relationen mellem kvinder og mænd, men danner basis for egne hierarkier. Selvom Rubin senere har "opblødt" sit standpunkt, hvilket bl.a. fremgår tydeligt i det tidligere omtalte interview, "Sexual Traffic", er det hendes tekst, som der henvises til i forskning, der bygger på denne distinktion. Se fx. introduktionen til The Lesbian and Gay Studies Reader (Abelove et al.1993), samt Sedgwicks "Axiomatic" i Epistemology of the Closet (Sedgwick 1990). For en kritik af (u)frugtbarhe den af skellet kan henvises til Biddy Martin's artikel, "Sexualities Without Genders and Other Queer Utopias" (Martin 1994).

8. Jf. Stormhøj 1999, kapitel 5. Jf. også Lindholm 1996, Søndergaard 1996: 107ff.

9. Identitetskategoriernes standardiserende karakter viser sig, hvad enten de figurerer som normaliserende redskaber for undertrykkende strukturer eller som samlingspunkter for en frigørende kamp imod en sådan undertrykkelse.

10. Jeg bruger betegnelsen "klassisk" feministisk teori for de feministiske positioner, der har det til fælles, at de tager udgangspunkt i kvinder og kvindelighed som homogene størrelser.

Jeg gør mig dermed skyldig i en grov nivellering af forskelle mellem de enkelte positioner. Formålet med den stærke generalisering er at indkredse en tankefigur med henblik på at rendyrke en paradigmatisk forskel mellem "klassisk" og poststrukturalistisk orienteret feministisk teori; altså forskellen mellem at tænke $\mathrm{i}$ identitet versus at tænke $\mathrm{i}$ forskel.

11. Et eksempel er: "Det er en dreng", som jordmoderen/lægen udtaler i føds øjeblikket. Denne ytring, der "kønner" barnet, transformerer det fra et "det" til et "han", hvormed barnet først bliver kulturel forståeligt; kan genkendes og anerkendes. Den medicinske anråbelse udgør det grundlæggende performativ (Butler 1993a, 7f).

12. Udsagnsordet to perform betyder at udføre eller gennemføre. Ifølge Austins talehandlingsteori (Austin 1962) er en ytring performativ, når de ord man udtaler ikke beskriver et sagsforhold, en formodning, et spørgsmål eller et ønske, men når selve udtalelsen af ordene implicerer udførelsen af en handling. En performativ sætning er således en, der forandrer virkeligheden eller skaber en ny vir- 
kelighed. I sin reformulering af begrebet om det performative argumenterer Derrida, at det ikke er i kraft af subjektets vilje eller intention, at det navngivne fænomen bringes til live. Snarere făr den performative ytring sin konstituerende kraft ved at henvise til en forudgående autoritet; altså ved at citere autoriteten (Derrida 1988).

13. Denne tolkning af Foucault ligger på linie med Butlers (Butler 1997c: 90f).

14. Kort fortalt argumenterer Freud for, at jeg'et, som primært anskues som et kropsligt jeg, først bliver oplevelsesmæssigt tilgængeligt gennem den forestilling, som man har af sin krop (Freud 1983). En given kropsdel konstitueres gennem en psykisk investering eller libidinøs besættelse, for først herigennem kan den opleves. Lacan vrider og videreudvikler denne tese i sin forståelse af subjektdannelsen ifølge hvilken, det er umuligt at bestemme den kronologiske rækkefølge af det psykiske billede af kroppen og den fysiske krop (Lacan 1977). Han hævder, at det psykiske kropsbillede er selve betingelsen for, at den kropslige materialitet fremtræeder og kan opleves.

15. Den endelige sammenkædning af Foucaults og Lacans argumentation er et resultat af, at elementet af forbud i den psykoanalytiske forståelse af identifikation reformuleres indenfor en magtanalytisk ramme. Det repressive moment anskues om en effekt af en regulerende magt i foucauldiansk forstand (Butler 1993a: 64). Konkret vil det sige, at når en kvinde identificerer sig som kvinde, betragtes det som udtryk for en social tvang, eftersom forbindelseslinien mellem en bestemt anatomi og en bestemt identifikation ikke er givet.

16. Jf. de tidligere omtalte internt konstruktivistiske problemer, som Butlers teori var et forsøg på at (op)løse.

\section{LITTERATUR}

- Austin, John (1962): How to Do Things with

Words. Oxford University Press, Oxford.

- Butler, Judith (1990a): Gender Trouble. Feminism and the Subversion of Identity. Routledge, New

York \& London.

- Butler, Judith (1990b): Gender Trouble, Feminist Theory, and Psychoanalytical Discourse, in Linda Nicholson (ed) Feminism/Postmodernism. Routledge, New York \& London.

- Butler, Judith (1993a): Bodies That Matter. On

The Discursive Limits of "Sex". Routledge, New

York \& London.

- Butler, Judith (1993b): Imitation and Gender
Insubordination, in Henry Abelove et al.(eds) The Lesbian And Gay Studies Reader. Routledge, New York \& London.

- Butler, Judith (1995a): Contingent Foundations, in Seyla Benhabib et al. Feminist Contentions. A Philosophical Exchange. Routledge, New York \& London.

- Butler, Judith (1995b): For a Careful Reading, in Seyla Benhabib et al. Feminist Contentions. A Philosophical Exchange. Routledge, New York \& London.

- Butler, Judith (1997a): Against Proper Objects, in Elizabeth Weed and Naomi Schor (eds) feminism meets queer theory. Indiana University Press, Bloomington and Indianapolis.

- Butler, Judith (1997b): Sexual Traffic. Interview med Gayle Rubin, in Elizabeth Weed and Naomi Schor (eds) feminism meets queer theory. Indiana University Press, Bloomington and Indianapolis.

- Butler, Judith (1997c): The Psychic Life of Power. Theories in Subjection. Standford University Press, Standford.

- Derrida, Jacques (1988): Signature, Event, Context, in Gerald Graff (ed) Limited, Inc. Northwestern University Press, Evanston.

- Foucault, Michel (1980): Two Lectures, in Colin Gordon (ed) Power/Knowledge. Selected Interviews and Other Writings. The Harvester Press, New York.

- Foucault, Michel (1982): Why Study Power: The Question of the Subject. Efterord, in Hubert Dreyfus and Paul Rabinow: Michel Foucault.

Beyond Structuralism and Hermeneutics. The Harvester Press, Chicago.

- Freud, Sigmund (1983): Jeg'et og det'et, in Ole Andkjær Olsen, Børge Kjær \& Simo Køppe (eds.) Metapsykologi 2. København, Hans Reitzel.

- Kotz, Liz (1992): The Body You Want. Interview med Judith Butler, in Artforum.

- Kulick, Don (1996): Queer Theory: Vad är det och vad är det bra för?, in lambda nordica 1996/3-4.

- Lacan, Jacques (1977): The Mirror Stage, in Ircrits: A Selection, tr. Alan Sheridan. Norton, New York.

- Lindholm, Margareta (1996): Vad har sexualitet med kön att göra?, in lambda nordica 1996/3-4.

- Sarup, Madan (1988): An Introductory Guide to Post-structuralism and Postmodernism. Harvester Wheatsheaf, New York.

- Seidman, Steven (1995): Deconstruction queer theory or the under-theorization of the social and the ethical, in Linda Nicholson and Steven Seidman (eds.) Social Postmodernism. Beyond identity 
politics. Cambridge University Press, Cambridge. - Simonsen, Dorte (1996): Som et stykke vådt sæbe mellem fedtede fingre, in Kvinder, Kon e Forskning 1996/2.

- Stormhøj, Christel (1999): Kønnet vi tenker, kønnet vi gør. Københavns Universitet: Sociologisk Institut, ph.d.-afhandling nr.7.

- Søndergaard, Dorte Marie (1996): Tegnet på kroppen. Køn: Koder og konstruktioner blandt unge voksne $i$ akademia. Museum Tusculanums Forlag, København.

- Young, Robert (1981): Untying the Text: A Poststructuralist Reader. Routledge, London.

\section{SUMMARY}

This article introduces the work of Judith Butler, whose theory of gender performativity has become highly influential in contemporary studies of gender and sexuality. Her main thesis is that both gender and sex are produced by discourse. In order to deal with the discursive construction of bodies, it is necessary to move beyond the opposition between sex and gender long upheld in feminist theory. Butler's theory is intended as an improvement on constructionism. Understanding construction as involving the materialization of determinate types of bodies through the iteration of gender-constituting performatives, she argues that both sex and gender are cooriginal effects of this process. The function of performatives is to create heterosexually structured bodies and subjects, and these performatives operate by prescribing certain sexed identifications and proscribing other identifications. Because there is never any easy fit between the stream of identifications and desires and the performativity of prescribtions and proscribtions, identities are always phantasmatic. The constitution of a heterosexually organized, gender differentiated identity rests on that which has been excluded and abjected to a domain outside intelligibility. From this sphere, the ex-communicated can rise to insubordination. The domain of abjection figures as a critical resource in the struggle to rearticulate the terms of symbolic intelligibility and legitimacy in Butler's political vision.

Christel Stormhøj ph.d., ekstern lektor RUC 